\title{
An Approach to Prospective Primary School Teachers' Concept of Environment and Biodiversity through their Design of Educational Itineraries: Validation of an Evaluation Rubric
}

\author{
Hortensia Morón-Monge ${ }^{1, *} \mathbb{C}$, María del Carmen Morón-Monge ${ }^{2}\left(\mathbb{D}\right.$, Daniel Abril-López ${ }^{3} \mathbb{C}$ and \\ María Paula Daza Navarro ${ }^{4}$ \\ 1 Departamento de Didáctica de las CC. Experimentales y Sociales, Universidad de Sevilla, 41013 Sevilla, Spain \\ 2 Departamento de Didácticas Integradas, Universidad de Huelva, 21007 Huelva, Spain; \\ mcarmen.moron@dhis2.uhu.es \\ 3 Departamento de Geología, Geografía y Medio Ambiente, Universidad de Alcalá, 19001 Guadalajara, Spain; \\ daniel.abril@uah.es \\ 4 Departamento de Biología Celular, Universidad de Sevilla, Av. Reina Mercedes s/n, 41012 Sevilla, Spain; \\ pdaza@us.es \\ * Correspondence: hmoron@us.es
}

Received: 10 May 2020; Accepted: 7 July 2020; Published: 9 July 2020

\begin{abstract}
The aim of this work is to promote outdoor activities to bring students closer to the environment and the biodiversity of their surroundings. In this sense, educational itineraries are a very good educational resource that promotes skills developing (scientific, cartographic, educational, etc.) which are necessary for the appropriate design of teaching proposals. The present study is carried out with the prospective primary teachers from the Universities of Sevilla and Huelva (Spain). Firstly, the purpose is to analyse what type of educational itineraries they can design after an outdoor activity. Secondly, a rubric is validated as an instrument of analysis and evaluation immersed in a qualitative methodology. The results show what kind of itineraries are designed, and what knowledge and conceptual difficulties the students display. Most of them do not recognize the minimal of elements making up the itineraries, and have difficulties in understanding the environment as a complex system. In summary, we think that the students' lacking of knowledge about the environment and its biodiversity, the poor geographic-cartographic competencies that they have, together with their maintenance of traditional conceptions of teaching, do not allow them to design proposals of interest for teaching-learning processes.
\end{abstract}

Keywords: educational itinerary; teacher training; biodiversity; science education; rubric; interdisciplinary

\section{Introduction}

Nowadays we live in a world marked by great problems and socio-environmental inequalities. The recent global health crisis of COVID-19 is not an isolated case of this problem. As announced in 2015 by the UN in the 2030 Agenda on Sustainable Development, we are in a climate emergency situation. As teacher educators or teacher trainers we believe it is necessary to address these environmental issues with our students. In this case our students are the future primary teacher or primary pre-service teachers. For that, we must integrate of Education for Sustainable Development (ESD) in university higher education. In this sense, with this study, we focus in outdoor education. We think that outdoor activities can be an important teaching resources to treat topic such as Biodiversity and its 
preservation problem, among some of its multiple educational opportunities. Its involvement in the teaching-learning processes depends on the educational approach that the teacher confers on it $[1,2]$. In this sense, we understand as a desirable educational approach that which allows us to achieve a scientific literacy of future teachers.

As background to this study, some results have been published on outdoor activities with primary pre-service teachers [3]. Likewise, we can find abundant bibliography on the importance of field trip for teaching and in particular for teacher training [4-9].

However, studies related to outdoor activities such as educational itineraries from teacher training are less frequent, as we will see later justified. Specifically, on our subject of study, teacher training and the analysis of itineraries as outdoor educational activities, there are no precedents. Although we later define the concept of educational itinerary among other associated terms, we anticipate that the concept of educational itinerary can have different meanings. Furthermore, from the Spanish context it may have different meanings and characteristics than on the international scene.

The present work is carried out with the prospective primary teacher lead them by a group of teachers and researchers from different areas (Cellular Biology, Environmental Science, Geography, and Contemporary History) who teach for the education faculty. We configure an interdisciplinary group of professionals with a common point which is the future teacher training. From this interdisciplinary approach, we describe this work. As teacher educators in science education (science and social science), we aim to teach our students science by "doing science" with them. This means that we as teachers are going to be your reference educational models for tomorrow with your future students. Consequently, prospective primary teachers need to learn scientific knowledge and skills (question formulation, hypothesis making, observation, data management, etc.). From this educational approach are designed and carried out the outdoor experience which is presented here.

In this context, this work arises where the primary prospective teacher, after completing a field trip, designs an outdoor educational activity, educational itinerary, using the space visited as an educational resource. The region where this outdoor educational experience is framed is a key element in this research from the point of view of biodiversity.

Spain is the country with the highest biodiversity in all of Europe, being the region of Andalusia, the one with the highest concentration of biodiversity in all of Spain. Andalusia is known for being a biodiversity hot spot and it is in this region that this outdoor educational experience takes place. This is because Andalusia is a "biogeographic bridge" between Europe and Africa. For example, it is an important area for migratory birds such as Doñana (National Park) or Laguna Fuente de Piedra (Natural Park). Similarly, we can find a lot of endemic plant species such as: the fir, the rhododendron, the erika andevalensis, etc.

The selected natural space, Sierra Norte de Sevilla, is a protected Natural Park, being one of the most biodiverse ecosystems in Europe: the Mediterranean dehesa [10].

Bearing in mind the panorama previously exposed. This study has a double objective. On the one hand, to explore what kind of educational itineraries the primary prospective teacher designs, and what vision of the environment and its biodiversity have after an educational outdoor experience. On the other hand, to validate a rubric as an instrument for evaluating and analysing educational itineraries as an educational outdoor activity. Our goal is to be able to detect training needs and possible learning difficulties related to your scientific (specifically the notion of environment and biodiversity) and educational knowledge (design of outdoor activities).

\section{Theoretical Framework}

\subsection{Biodiversity: A Challenge for Its Understanding and Construction in School}

According to the International Convention on Biological Diversity (CBD) of 1993, biodiversity is understood as all the living beings that populate the Earth, a result of billions of years of evolution together with the influence of humans. Educationally, according to Harlen [11], one of the great ideas 
of science in Primary and Secondary Education is the diversity of living and extinct organisms as a result of evolution.

The notion of biodiversity and the problems of its conservation constitute one of the great challenges in the school environment. It is a difficult construct to teach in the classroom due to its complexity and high degree of abstraction [12,13]. Likewise, the fact that textbooks are the preferred resource in primary education teaching in Spain makes its appropriate teaching treatment even more difficult. Some studies $[12,14]$ have highlighted the limitations of this school material. The concept of biodiversity is addressed in the textbooks of the 3rd and 4th years of Primary Education (in the subject of Environmental Knowledge) from an atomized perspective, making a separation between living beings but without putting forward the connection between them. Another aspect is the lack of relationship between biodiversity and conservation. There is hardly any link made of the idea of biodiversity with values and aptitudes prone to respecting and conserving nature. And, really, who does not know, does not value.

The way biodiversity is treated in the official curriculum and school textbooks proposes a partial form of content sequencing. Consequently, this has an impact on its teaching and learning in Primary Education. From the teaching point of view, the phenomenon is approached with no connection to ecosystems or environmental problems, with no definite or continuous thread. From the learning point of view, the pupil's knowledge is biased, and misses any holistic vision and understanding of the different problems of the phenomenon in its entirety. This situation also extends to Secondary Education, with the addition of not contemplating the social dimension in the visions given of the phenomenon [12,13]. On the contrary, the focus is on an anthropocentric and utilitarian perspective of nature, which does not favour the formation of critical citizens with decision-making capacities concerning environmental issues [15]. In summary, the current approach in classrooms to biodiversity is far from fostering attitudes towards sustainability that will allow pupils to face the challenges of conservation of that biodiversity.

It should also be noted that the examples related to biodiversity proposed in the textbooks for both Primary and Secondary Education in Spain tend to refer to tropical biomes [12]. Other types of ecosystems with high biodiversity which are found within the territorial context of the Iberian Peninsula (wetlands, coastal ecosystems, and mediterranean forest), closer to the pupils, have little or no representation in school textbooks [13]. In this sense, the dehesa system (a managed, parkland-type, open mediterranean woodland), which originated from the secular action of humans in combination with the natural processes of sclerophyllous forest and scrubland [16], is a closer example for pupils, and has great biological and sociocultural richness. This traditional agrosilvopastoral system, characterized by large estates and scattered rural settlements, has allowed extensive cropping systems (grassland, woodland, scrubland, cereal cropland, etc.) to coexist with a high number of animal and plant species [10,16-18].

To comprehend this ecosystem and its biodiversity, it is necessary to understand that the culture and society of a territory determine its ecological functioning, and that rural ways of life are largely in line with environmental and social sustainability. For all these reasons, the concept of biodiversity takes on a social and even patrimonial dimension, since it acquires an identity through appropriation by a society or a certain cultural group [19].

To understand this phenomenon comprehensively and systemically, prospective primary school teachers need to know the specific territorial and environmental context in which it arises. Therefore, field trips allow first-hand contact and facilitate understanding nature's role in human societies and vice versa, in a meaningful and revealing way.

\subsection{Outdoor Education and Their Interest for Teacher Training}

There are institutions (such as the National Research Council [20]) and reports that are both international (such as Rocard [21]) and Spanish (such as ENCIENDE [22]) which recommend that science teaching be real and of an everyday nature for it to be useful for pupils' day-to-day lives. 
These recommendations are reflected in the Spanish curriculum set out in the Organic Law 8/2013, December 9, for the improvement of educational quality (LOMCE) [23], and particularly in the Order of 17 March 2015 which develops the curriculum for Primary Education in Andalusia [24], emphasizing the relevance of using natural and sociocultural spaces as learning scenarios. For the area of Natural Sciences, it explicitly proposes outdoor activities as a teaching resource: school gardens, botanical gardens, animal care, carrying out itineraries, etc. And for the area of Social Sciences, it proposes diverse field trips-to firms, factories, protected areas, monuments, etc.-in order to achieve more contextualized learning, improved understanding of the geographical space, and strengthened cartographic skills (design and interpretation of maps, plans, and layout sketches) [25,26].

From the Inquiry-Based science education approach, they promote a construction of knowledge from the observation of natural phenomena and experimentation in the environment [27-32]. This is the way in which the human being has been creating his knowledge and culture throughout the centuries. Some examples have been recorded in monumental form as we can verify in a multitude of ancient civilizations (Egyptian, Phoenician, Mayan, etc.) and even prehistoric such as the Stonehenge megalithic complex (United Kingdom). In them it is observed how the human being has developed his knowledge from the observation of the stars, phases of the Moon, the migration of animal specificities, etc. Consequently, Nature is the scene of direct and in situ experimentation with natural phenomena and therefore of "natural" human learning. For this reason, it is not only important to carry out experimental activities in the laboratory with "controlled" variables to generate knowledge, but also an outdoor education approach in our nearby environment. From observation, the process of scientific inquiry and the construction of scientific knowledge begins in this way.

Along the same line, the research by Zamalloa, Sanz, Maguregi, Fernández \& Echevarría [33] defends the contribution of outings to the construction of scientific knowledge, and of specific knowledge of Biology or Geology from a holistic point of view. Morales, Caurín, Sendra \& Parra [34] consider the development of scientific strategies. Tal \& Morag [35] argue in support of how this type of activity produces teaching experiences in an interactive environment, which contributes to experiential and meaningful learning. In addition, these outings sensitize pupils about the socio-natural space and the defence of attitudes of respect and sustainable care [34,36-38].

This approach is not recent. Its antecedents lie in the Free Institution of Education (ILE) in 1876 (Spain), and in the educational principles of the Modern School promoted by Spanish Francisco Ferre i Guardia at the beginning of the 20th century. These schools promoted an integral outdoor education of the individual (using "natural methods" or hiking) based on understanding nature as a source of learning. In the present study, we refer to a way of intimately connecting the individual with their close environment, and of acting when faced with its destruction [39]. For more than a hundred years, it has been recognized that outdoor learning, through observation and experimentation, favours scientific learning that is far removed from dogmatic, ideological, or clerical approaches. Among its educational benefits, attention is paid to its objectifying thought by expressing, ordering, and systematizing ideas, in addition to reflection on that thinking.

The benefits that outdoor learning is not only educational, but also emotional, physical, and psychic by improving stress management $[40,41]$. Despite its educational relevance, there have been few non-university educational proposals, and even fewer directed at initial or ongoing teacher training $[33,36,37,42]$.

This difference becomes more noticeable by areas. Recent studies $[37,43,44]$ indicate the lack of outdoor activities such as field trips in the sciences education. Many of the teaching proposals are traditional, applied as a means of testing theoretical knowledge, and without any clear educational integration. They are usually sporadic activities unrelated to the curriculum [44] and are therefore unlikely to favour the teaching-learning processes [2]. However, one finds a multitude of teaching proposals focused on the socio-natural environment for other disciplines, especially in the Didactics of Geography area. Thus, for example, a recent publication of the Spanish Geography Association (AGE) describes outdoor teaching experiences in Geography. However, there have still been very few 
proposals directed at teacher training. Mateo [42] made a bibliographic analysis of 946 studies in the area of Didactics of Geography, and concluded that only $10 \%$ of them were related to outdoor learning, and only $39 \%$ of these were aimed at teacher training.

Our teaching experience was designed from an interdisciplinary outdoor learning approach. It is a proposal integrated into the teaching plans, and which encourages the students' curiosity about school inquiry, and promotes the acquisition of scientific skills and knowledge about the environment and the biodiversity of their neighbouring territory.

\subsection{Educational Itineraries: Conceptualization and Educational Opportunities for Science Education}

Despite the existing literature about teaching experiences based on itineraries, there have been few conceptual delimitations about what to understand by itinerary, and by educational itinerary. Jerez [45] distinguishes between educational itinerary and educational hiking: the latter is defined as a physical support (path) with an infrastructure (signposts and markers) where physical and intellectual activity is carried out within a curricular context.

On the contrary, Guerra [46], in the manual published as "Practical Guide: Itineraries in the Natural Environment", defines paths as exclusively the physical support that make up the itineraries. From this perspective, the itinerary is made up of a path and a signposted medium of communication, with stops and places of interest. The itineraries take advantage of the environmental circumstances (elements of the place, landscape, its physiognomic characteristics, accessibility, etc.) to communicate to the visitor the values of that site and its conservation needs.

An itinerary should thus help in the interpretation of the heritage and landscape of a given place. Thus, a distinction is made between an interpretive and an educational itinerary: they are differentiated by the target audience and the objectives or purposes. An interpretive itinerary is aimed at all audiences, and its purpose is communicative-recreational. An educational itinerary is focused on pupils in a regulated education setting. Furthermore, the latter transcends the purpose of communication about the environment: its main objective is to generate knowledge (about biological, geological, sociocultural, artistic, etc., aspects) from analysis and interpretation, in a planned manner, of the most characteristic socio-natural features or elements of the place [46]. An educational itinerary (EI) allows attention during the outing to be paid to different aspects of a reality that the visitor would not normally notice [47]. Likewise, to go from a plain itinerary to an EI, it is necessary for the socio-natural elements of the place, its most notable landmarks or features (in the form of stops), to be valued as teaching resources. To this end, the design of the EI has to have an explicit educational purpose as part of a teaching plan (whether of formal or non-formal education) that allows it to be used as a true teaching resource.

Hence, it is not only necessary to formulate educational objectives that serve as a plot line throughout the outing, but these must be conveniently integrated into three stages: before, during, and after the field trip. From this same perspective From this same perspective, Liceras [48] considers that an EI is a kind of outdoor education which gather the characteristics of three types of itineraries (experiential, experimentation, and social participation) corresponding to the three moments of undertaking a field trip (before, during, and after). Carrying out an EI is not an improvised excursion [42,48]. If there is no pre-departure planning, the activity is de-contextualized from the teaching-learning process, and if there is no evaluation of the activity, the itinerary will not provide much information to the teachers in order to assess this experience in the pupil's overall learning [43,49].

Consequently, like any educational activity (inside or outside) in this case, in the form of an EI, must be carried out with an educational objective and with a previous teaching plan. These activities, designed within the itinerary, are usually done at the different stops that make up the itinerary, paying attention to some feature or set of socio-natural elements in the environment. It is with and from these that learning will be built. Likewise, Guerra [46] advises that for the design of an itinerary—without distinguishing between interpretive or educational—there should be a central theme or a common thread of the selected itinerary, making it necessary to make a prior inventory of the 
most notable or outstanding elements of the place. Therefore, the different activities carried out must be carefully designed and selected. Depending on how they promote visitor-environment relationships, they will foster identifying values with that place. I.e., the individual, through experimentation with the environment-be it in the form of a game, exploration of the place, taking data, observing, feeling or perceiving the place, etc.-will connect with the territory or the element under study so as to identify with it [19]. It is at that moment when this environment is valued as heritage, which favours conservation attitudes.

Integrating theory with practice and the stimulation of the pupil's interest, motivation and positive attitudes towards science (teamwork, dissemination of knowledge, etc.), are other educational aspects that can be achieved from outdoor learning [50].

All field trips that are well planned educationally, and with the use of socio-natural elements (biological, geological, anthropic, or physicochemical-perceptive), promote not only meaningful and contextualized learning, but also scientific skills (observation of the environment, experimentation, etc.) and conservationist attitudes regarding the heritage. In addition, an EI allows the learner to acquire a variety of skills: localization and map-reading, and historical knowledge to explain present situations and predict changes and transformations of the environment in the immediate future, among others $[47,48]$. In short, working in a specific geographic space allows the learner to decode the different elements that interact in that space, what physical and chemical phenomena take place, as well as to develop a systemic view of the environment as a result of past and present processes and phenomena where humans intervene.

\section{Materials and Methods}

\subsection{Research Questions}

Given the objectives of this study, our research questions were:

- Main question. After an outdoor learning experience in a socio-natural environment close to their future pupils, what type of EI prospective primary education teachers design?

- Sub-questions:

- Assessment using the rubric. Bearing in mind that there are no previous referents that propose instruments with which to value and evaluate educational itineraries, how can these designs be evaluated objectively and systematically?

- Biodiversity learning and educational needs. As teacher educators, what are the main educational needs and learning difficulties about the biodiversity and its teaching in order to enhance the primary teacher's formation?

\subsection{Participants and the Teaching Proposal Context}

This experience, EI design, was carried out with a group of 119 Primary Education Bachelor's Degree, in two subjects: Sciences Education (62 students) of the University of Sevilla (Spain), and Social Sciences Education (57 students) of the University of Huelva (Spain). During the first four-month term, they study science (how it is constructed and what its nature is). In the second, they design teaching proposals following an Inquiry-Based science education approach. This proposal is designed in three phases following other outdoor proposal such as that described by Liceras [48]: before (in classroom: site selection and field trip preparation), during (field trip: where field data is collected through observation), and after (in classroom: analyze collected data and EI design from Inquiry-Based approach).

The Sierra Norte de Sevilla was selected as a place of interest for the design of the itinerary due to its environmental value and representativeness for pupils. The geographical aspect is an important variable since activities in pupils' close environment foster their interest and motivation because of the emotional bond that it arouses in them. 
The area of the Sierra Norte de Sevilla is hill-country that alternates extensive dehesas with lush riparian forest. It belongs to the Dehesas de Sierra Morena Biosphere Reserve, and to the European Network of Geoparks. This territory therefore allows activities to be carried out that are of interest both for science education (related to biological and geological scientific knowledge) and for working on social, cultural, and geographic skills. These aspects are of great interest to understand in a holistic way the biodiversity offered by that area of the Autonomous Region of Andalusia (Spain). It is an area that favours the development of interdisciplinary knowledge to value the environment systemically. To carry out the activity, a nature centre located in the municipality of Cazalla de la Sierra (Sevilla, Andalusia, Spain) was selected.

- Phase 1. Before the field trip some aspects related to the area to be visited were studied in class: its geographical location, its most representative sociocultural, biological and geological characteristics, and any previous ideas the students had about it (Table 1). To collect the prior knowledge we did several activities: a brainstorming and debate (asking about main place' features to visit); from different pictures (vegetation, villages, animals) belonging to the place to visit (trying to recognize the image); and with a blank map to assess if they could locate the area on the map. Finally, the students were divided into groups of $4-5$ (a total of 28 groups) to plan the data collection process during the field trip.

- Phase 2. During the field trip a guided itinerary was carried out accompanied by nature-guides, in which the students took notes based on the observation and analysis of the territory. The length of the itinerary is about $3,3 \mathrm{Km}$ and its duration was two hours and a half. Although it is possible to finish the route faster, we did some breaks and some stops to collect data and ask questions. In relation to the difficulty of the route is low and there is no possible risk during the whole it. The chosen area corresponded to a part of an old rural road of the Ruta de la Plata, a roadway configured in times of the Roman Empire, and used, for example, by the Carthusian monks during the 15th century. From the geological point of view, this territory is located on the margins of the Sierra Morena, made up of a broken relief of Precambrian rocks in contact with sedimentary materials from the Quaternary. The result is a morphology of mountain ranges, hills, and crags, cut through by embedded valleys that drain towards the Baetic Depression [51]. The path taken is within this geomorphological context. It is circular, first climbing and then descending the side of a hill. Thus, different environments and more or less human-modified ecosystems can be observed-from a valley crossed by a stream and its corresponding gallery forest, to widely varied hill vegetation (olive groves, chestnut woods, and cork and holm oak dehesas) combined with cropland and pastureland for free-ranging cattle, swine, and sheep. During this route, the students made an inventory of the resources or possible socio-natural elements that the place offers, to later design the stops that make up the EI.

- Phase 3. Finally, after the outdoor experience, the field data were shared and analysed in the classroom by future teachers. In this way, students build together the knowledge about the visited place. Finally, they designed the EIs about the visited place. Every group of students selected a theme (educational content) which will be the central topic of the activities of the itinerary. Likewise, they chose the best way to represent their itineraries. For this last part, we carry on a workshop about how to create an EI, its main features, and some examples of EI (imagens). During the workshop, we tried not to restrict the students 'creativity and just some guidelines were provided to design their IE. 
Table 1. Prior knowledge before the field trip.

\begin{tabular}{l}
\hline \multicolumn{1}{c}{ Some Examples } \\
\hline 1. The vast majority did not recognize the protected category of this natural space. \\
2. They were not able to accurately place the selected location on a map. \\
3. They recognized some of the most outstanding elements of the natural environment's flora (the dehesa \\
and some trees such as holm oaks and cork oaks) and fauna (mainly associated with local livestock). \\
4. They were unable to list native or protected wild animal species. The same was the case with \\
5lant species. \\
Regarding geological and relief aspects, they only recognized the most notable aspects of its geology \\
(mountains and rivers). They could not identify types of rocks, nor offer any information about \\
the climate.
\end{tabular}

Although we have described three phases, this is a circle process, so we can repeat it as times as we think convenient.

\subsection{Data Sources and Procedure}

After carrying out the field trip, the 28 EIs corresponding to the 28 work groups were designed. We collect different EI in the classroom. For that, every group displays their EI for about five minutes with the whole class. After the exposition, we, as teachers, ask them about the main doubts and provide recommendations about their works. The rest of the students can ask them too. In this way, we took note of the main activities that the students design for these EI. Moreover, in order to have more details about the EI and its design, every group provide a list of the different activities which configure the EI.

In order to evaluate them, a rubric was designed as a framework instrument for analysis (qualitative methodology). It was based on a hypothesis of progression [52] or learning progression [53,54] (Table 2A,B) as adopted in relevant research. The EIs were analysed using a system of emergent categories that were the consequence of a process of inductive coding [55] and intra- and inter-rater combination $[15,56]$. A preliminary classification of the EIs was made (1st analysis), with two of us, and this was later again subjected, this preliminary classification, to scrutiny by two other researchers (2sd analysis) in order to determine possible coincidences and discrepancies. The degree of concurrence was greater than $90 \%$. This means that the results of the first analyzed and the second analyses were very similar. The controversial cases were subjected to further discussion until a majority consensus was reached.

The rubric obtained consists of three levels of progression, with level III being the desirable or referent to be reached. These levels are not watertight, and intermediate situations (levels I-II or levels II-III) can be found. To avoid generalizing to only three levels, these are supported by a series of categories that allow a detailed evaluation. Specifically, we defined six categories that are encompassed in two large dimensions corresponding to the different elements that make up the EI: formal aspects, and teaching aspects with an educational implication. 
Table 2. (A) Rubric to evaluate educational itineraries (EI): Formal Aspects. (B) Rubric to evaluate educational itineraries (EI): Teaching Aspects.

\begin{tabular}{|c|c|c|c|}
\hline \multicolumn{4}{|c|}{ (A) } \\
\hline \multirow{2}{*}{ CATEGORIES } & \multicolumn{3}{|c|}{ LEVELS } \\
\hline & $\mathbf{I}$ & II & III \\
\hline 1. Type of itinerary & $\begin{array}{l}\text { The sense and direction of the } \\
\text { path is undefined (where it } \\
\text { begins, ends or continues). }\end{array}$ & $\begin{array}{l}\text { That of linear type. The } \\
\text { path is well defined with } \\
\text { a beginning and end. }\end{array}$ & $\begin{array}{l}\text { The one of circular type } \\
\text { (selects all the territory } \\
\text { visited): starts where it ends. }\end{array}$ \\
\hline 2. Number of stops & $\begin{array}{l}\text { Low number of stops } \\
\text { represented (4 or less); or they } \\
\text { are too many and little operative } \\
\text { or irrelevant. }\end{array}$ & $\begin{array}{l}\text { It has a sufficient number } \\
\text { of stops for the route it } \\
\text { designs (between 5-6). }\end{array}$ & $\begin{array}{l}\text { It has an optimal number of } \\
\text { stops from an educational } \\
\text { point of view (between 7-8). }\end{array}$ \\
\hline $\begin{array}{l}\text { 3. Location and } \\
\text { representation }\end{array}$ & $\begin{array}{l}\text { No location and no } \\
\text { representation-does not } \\
\text { establish geographic links for } \\
\text { selected items. Design a route, } \\
\text { but without representing the } \\
\text { stops / activities at specific } \\
\text { geographic points and without } \\
\text { making a geographical } \\
\text { representation of the place. You } \\
\text { have not completed a route. }\end{array}$ & $\begin{array}{l}\text { Location, but without } \\
\text { geographic } \\
\text { representation. It locates } \\
\text { the most outstanding } \\
\text { elements of the path in } \\
\text { specific points, but they } \\
\text { are decontextualized, } \\
\text { because the place is not } \\
\text { geographically } \\
\text { represented. }\end{array}$ & $\begin{array}{l}\text { Location or partial or complete } \\
\text { geographical representation. It } \\
\text { locates and contextually } \\
\text { represents the most } \\
\text { outstanding elements of the } \\
\text { path, including biological, } \\
\text { geological and geographic } \\
\text { aspects, from a systemic } \\
\text { perspective of the } \\
\text { environment. }\end{array}$ \\
\hline \multicolumn{4}{|c|}{ (B) } \\
\hline \multirow{2}{*}{ CATEGORIES } & \multicolumn{3}{|c|}{ LEVELS } \\
\hline & $\mathbf{I}$ & II & III \\
\hline 4. Theme & $\begin{array}{l}\text { Without integration: It does not } \\
\text { have an explicit theme or theme } \\
\text { thread, since there is no clear } \\
\text { educational link between the } \\
\text { elements used on the path. }\end{array}$ & $\begin{array}{l}\text { It has a theme, but } \\
\text { without being explicit or } \\
\text { having, a clear } \\
\text { educational purpose } \\
\text { among the elements used } \\
\text { as a teaching resource; or } \\
\text { the educational objective } \\
\text { of the itinerary is not } \\
\text { related to the selected } \\
\text { element. Disconnection } \\
\text { of the milestones of the } \\
\text { stops. }\end{array}$ & $\begin{array}{l}\text { It has an explicitly defined } \\
\text { theme that connects all the } \\
\text { different elements observed } \\
\text { along the route, based on one } \\
\text { or more educational objectives. }\end{array}$ \\
\hline 5. Socio-natural elements & $\begin{array}{l}\text { Collect, as teaching resources, } \\
\text { flora (trees, shrubs or plants), } \\
\text { fauna (wild or farm animals), } \\
\text { geological elements (water from } \\
\text { rivers, streams or ponds; soil; } \\
\text { rocks; etc.), materials anthropic } \\
\text { (infrastructures, wells, bridges, } \\
\text { houses, farms, mills, etc.), but } \\
\text { without establishing } \\
\text { relationships or links between } \\
\text { them. }\end{array}$ & $\begin{array}{c}\text { Mainly uses } \\
\text { physical-chemical and } \\
\text { perceptual-sensory } \\
\text { elements (humidity, } \\
\text { thermal sensation, } \\
\text { sounds of animals or the } \\
\text { environment, colors, } \\
\text { textures) to make the } \\
\text { stops on the itinerary. It } \\
\text { uses natural (geological } \\
\text { or biological) or human } \\
\text { elements. }\end{array}$ & $\begin{array}{l}\text { It gathers, as teaching } \\
\text { resources, environmental } \\
\text { elements that use and } \\
\text { interrelate different } \\
\text { physiological elements } \\
\text { (biological, geological and } \\
\text { human: landscapes, places, } \\
\text { spaces, etc.), connecting them } \\
\text { geographically with the place. }\end{array}$ \\
\hline 6. Designed activities & $\begin{array}{l}\text { Activities are designed without } \\
\text { a clear educational intention, or } \\
\text { oriented to recess and leisure: } \\
\text { dynamics or games to promote } \\
\text { confidence, perform some } \\
\text { physical activity, stops to rest or } \\
\text { eat, etc. Or decontextualized } \\
\text { activities are designed with the } \\
\text { resources and elements of the } \\
\text { medium. }\end{array}$ & $\begin{array}{l}\text { The activities have an } \\
\text { educational intent, but } \\
\text { are mainly traditional in } \\
\text { nature; Little or nothing } \\
\text { interactive with the } \\
\text { place, they do not } \\
\text { promote the exploration } \\
\text { of the place or the } \\
\text { development of scientific } \\
\text { skills: expository or } \\
\text { informative talks, free } \\
\text { observation, } \\
\text { contemplation of the } \\
\text { landscape, etc. }\end{array}$ & $\begin{array}{l}\text { The activities have an } \\
\text { educational intent, } \\
\text { predominantly those of an } \\
\text { interactive nature with the } \\
\text { environment (games, } \\
\text { exploration, directed } \\
\text { observation, collection of } \\
\text { elements / data from the } \\
\text { environment, etc.), and } \\
\text { promoting the development of } \\
\text { scientific skills with } \\
\text { contextualized learning. }\end{array}$ \\
\hline
\end{tabular}


The formal aspects are configured by three categories (1-3). Category 1 is the type of itinerary: linear, circular, or undefined. Category 2 is the number of stops designed, and the different landmarks or elements to work on. Category 3 is location and representation, i.e., how the geographical itinerary is represented graphically. These categories are based on the recommendations for itineraries of Guerra [46]. Category 3 is a category that we added as a formal aspect, taking into account the research by Olave [47] in the area of the Didactics of Geography, and the latest AGE monograph about field trips [42]. This category provides indirect information about how the students interpret the environment: contextualized (linking and relating the different physiognomic features with the environment or territory) or de-contextualized. This category helps to infer possible educational needs related to their conception of the medium and the territory, as well as their cartographic skills.

Three categories (4-6) are also used to configure the teaching aspects. Category 4 (theme of the itinerary) identifies whether the itinerary has an educational purpose, i.e., coherence between the selected element, stop, or landmark and the educational objective of the itinerary, or, on the contrary, it is a set of stops or activities with no connection between them or with no apparent coherence with the proposed educational objective.

Category 5 (socio-natural elements) allows the inventoried elements and how they will be used to be identified. This category is also related to category 3 since it helps us infer which conception of the environment prevails in the student, distinguishing three views: an undifferentiated view of the environment, a summative or intermediate perspective, and a systemic view as the referent [54,57-59]. Level I of this category shows us the selection of elements (flora, fauna, geology, or anthropic aspects) in isolation, without relating or establishing interactions with the environment or with other elements. It is an egocentric and conflict-free view that shows us just a partial vision of the environment in which sensations, objects, and relationships intermingle without any definite organization [60]. The other extreme, level III, corresponds to the selection of different types of socio-natural elements that are interrelated or take into account the place/territory where they are found. It is a view of the environment as a system where the different processes and elements of the socio-natural environment are recognized and related, overcoming anthropocentric and reductionist visions.

Category 6 (designed activities) aims to evaluate what type of activity is designed-anecdotal, recreational, or game-like; traditional; or, on the contrary, promoting both scientific skills and learning through school inquiry.

\section{Results}

After analysis of the $28 \mathrm{EI}$ we have classified the main results in two subsection (formal aspects and teaching aspects) which compose the evaluation rubric.

According to Figure 1, the predominant level in four categories $(2,3,4$, and 6$)$ is II (orange colour: from $14=50 \%$ to $16=57.14 \%$ ). Category 1 tends to be level III (green colour: $18=64.29 \%$ ), and category 5 tends to be level I (blue colour: $18=64.29 \%$ ). 


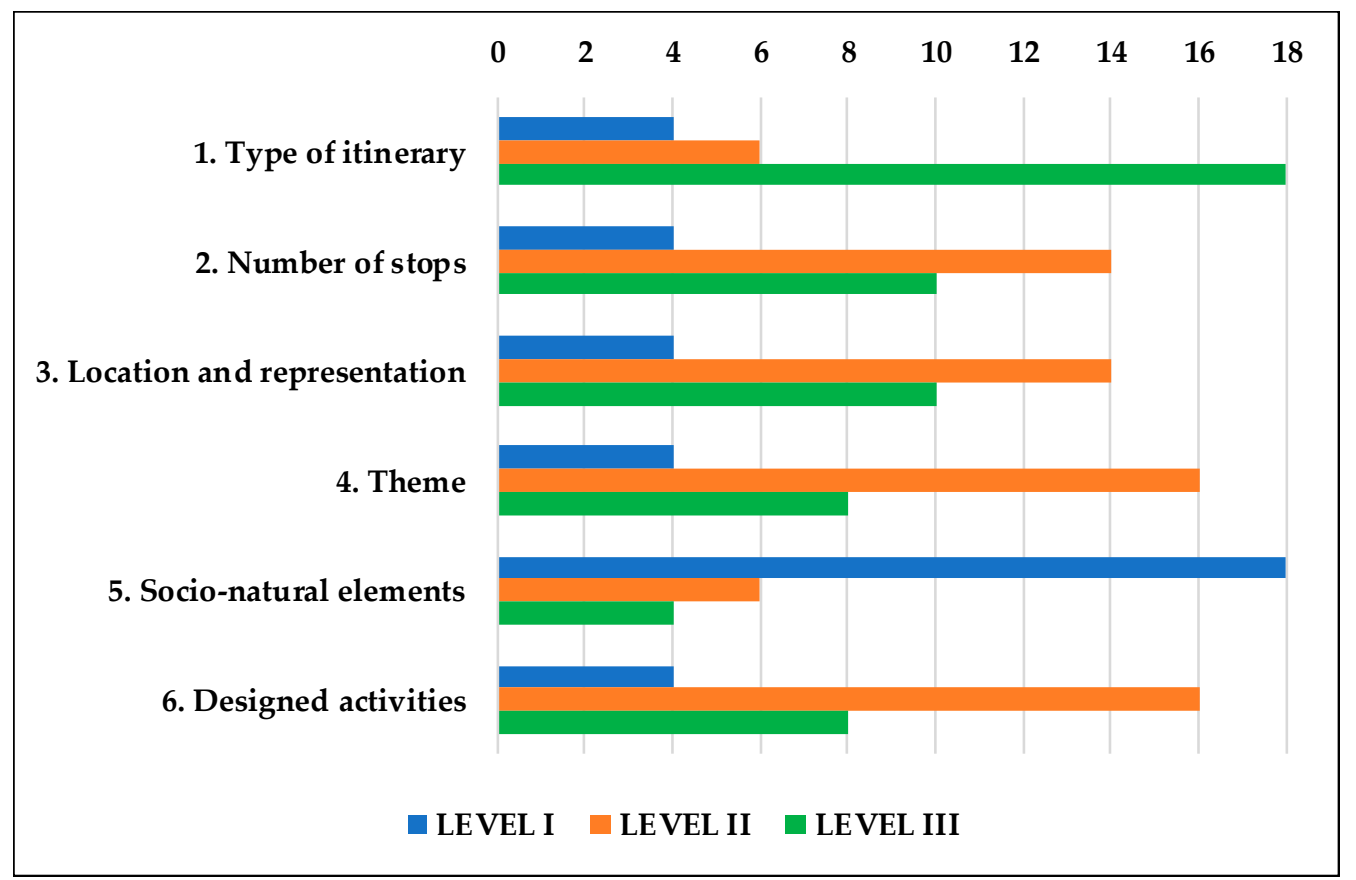

Figure 1. Educational itineraries (EI) by categories and levels of progression $(n=28)$.

\subsection{Formal Aspects}

For category 1 (type of itinerary), as observed in Figure 1, the students usually choose the circular type (level III: $18=64.29 \%$ ), which corresponds to the itinerary carried out during the field trip. Regarding category 2 (number of stops), there predominate those with 5 or 6 stops (level II: $14=50 \%$ ). Finally, for category 3 (location and representation), we found that the majority of the students represent the most outstanding stops or landmarks, and their proximity to the next stop (level II: $14=50 \%$ ), but without any spatial or cartographic basis (real or imaginary) to support them.

To exemplify this first dimension (formal aspects), we have chosen some images corresponding to the different itineraries designed by the students. Here can be seen, by categories (1-3) and levels (I-III), the most notable characteristics captured by the students. In Figure 2 we collect the different examples by levels to see easier the progression (the import here is not the content but the formal aspect) from a basic level until one reference.

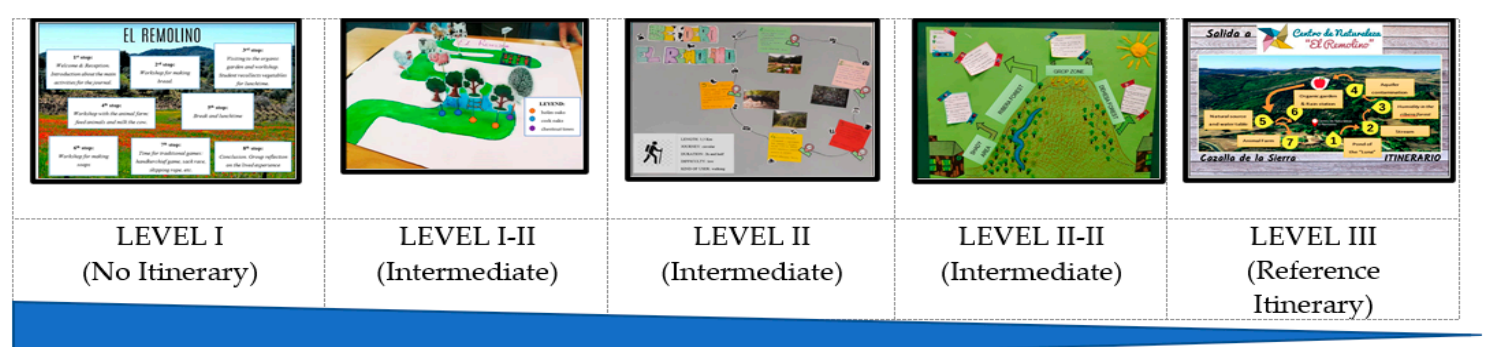

Figure 2. Examples by progression. [Source: adapted from student's work].

Example A. We observe how this is an undefined itinerary (neither linear or circular). Furthermore, it does not locate spatially each stop with the element or landmark to work with, and it does not have a cartographic base to support it (Figure 3). 


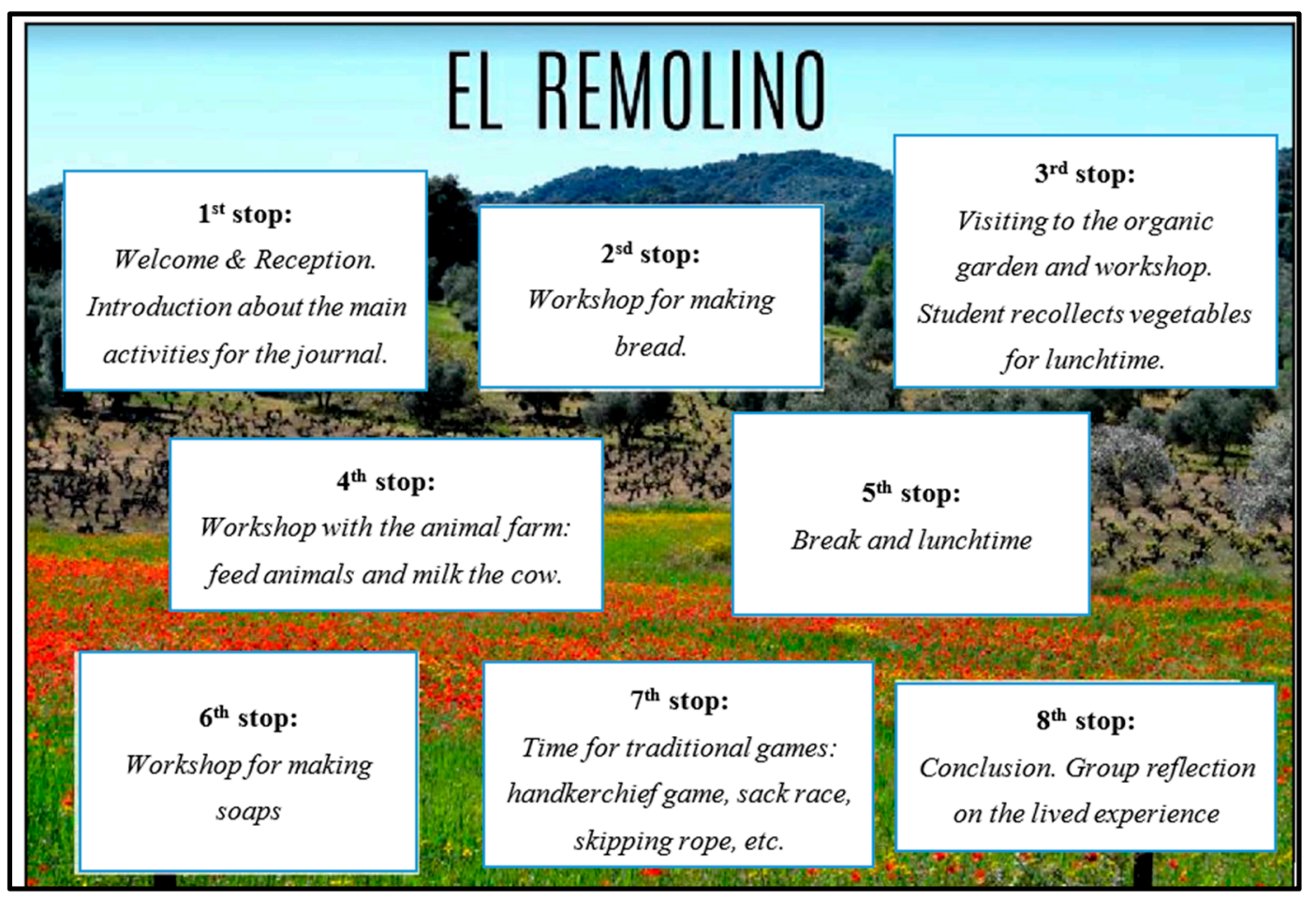

Figure 3. Educational itinerary (example A): category 1 (level I); category 2 (level II); category 3 (level I).

[Source: adapted from student's work].

Example B. We see a linear type itinerary in which a section is represented and selected for the design of the path. The most relevant elements of the place, corresponding to the stops and activities to be carried out, are represented by drawings. It should be noted that the representation of the place is imaginary, and does not correspond to reality (Figure 4).

Example C. We see a design of a circular itinerary, with the location of each element or landmark of the most outstanding stops, but without a cartographic or geographic base (Figure 5).

Example D. We see a circular itinerary which not only locates the different stops, but also has a cartographic base. In this case, we see a drawing that represents, in a simplified way as a sketch, the main geographical elements of the place (Figure 6).

Example E. We find level III in the three analysed categories. In addition, the students have used a real Google Earth photograph to represent the different landmarks and stops on the itinerary (Figure 7). 


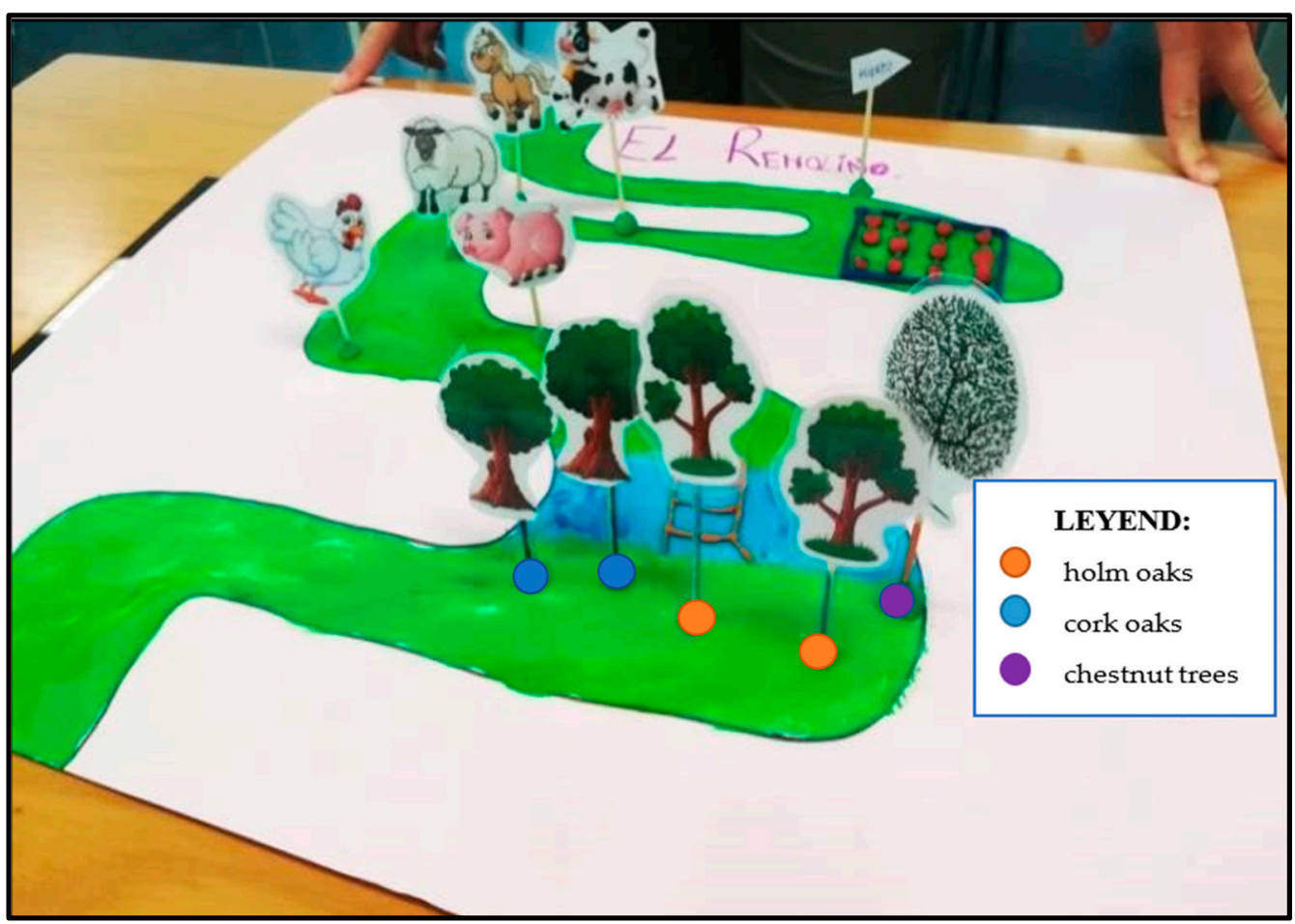

Figure 4. Educational itinerary (example B): category 1 (level II); category 2 (level I); category 3 (level III). [Source: adapted from student's work].

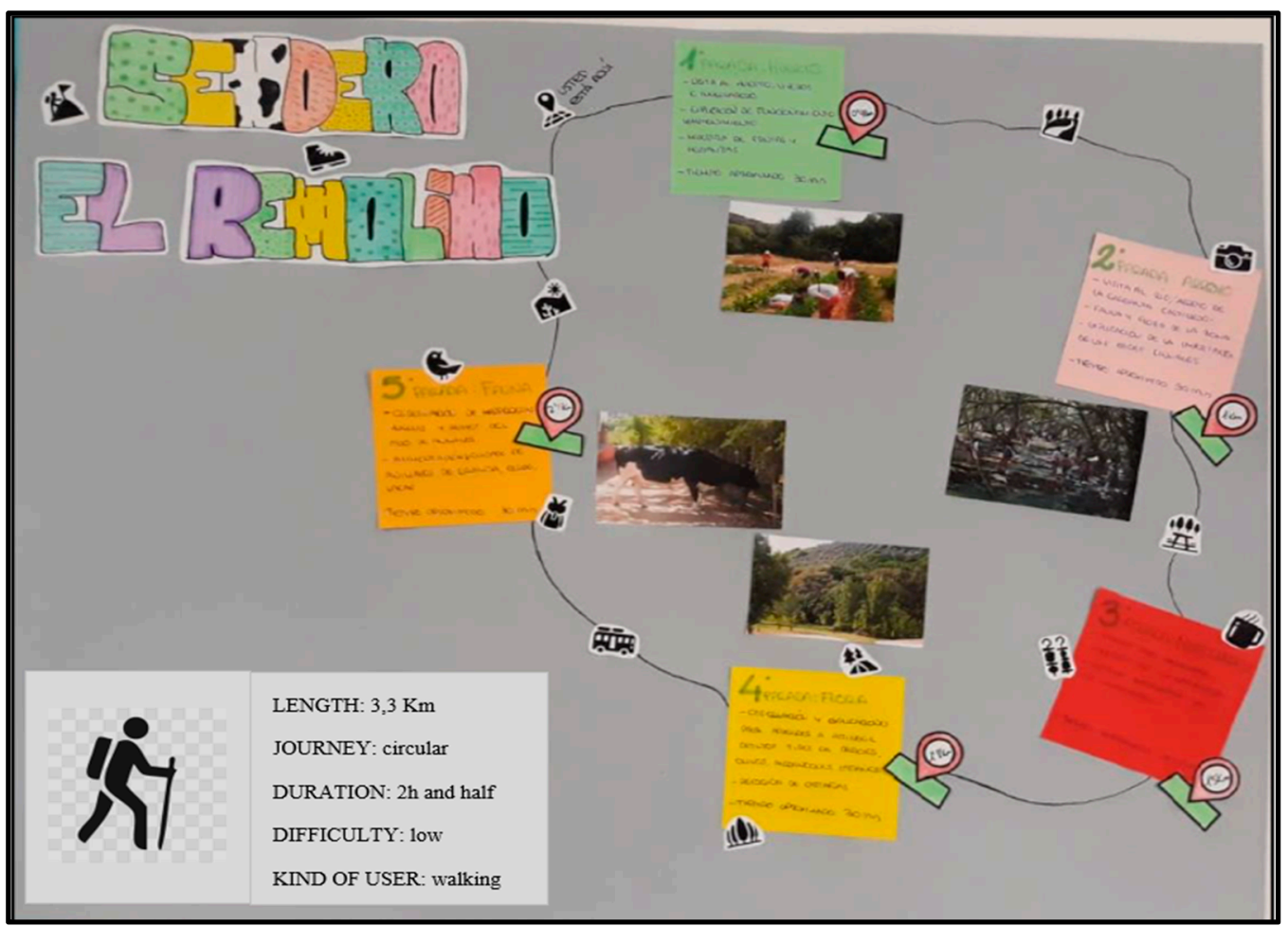

Figure 5. Educational itinerary (example C): category 1 (level III); category 2 (level II); category 3 (level II). [Source: adapted from student's work]. 


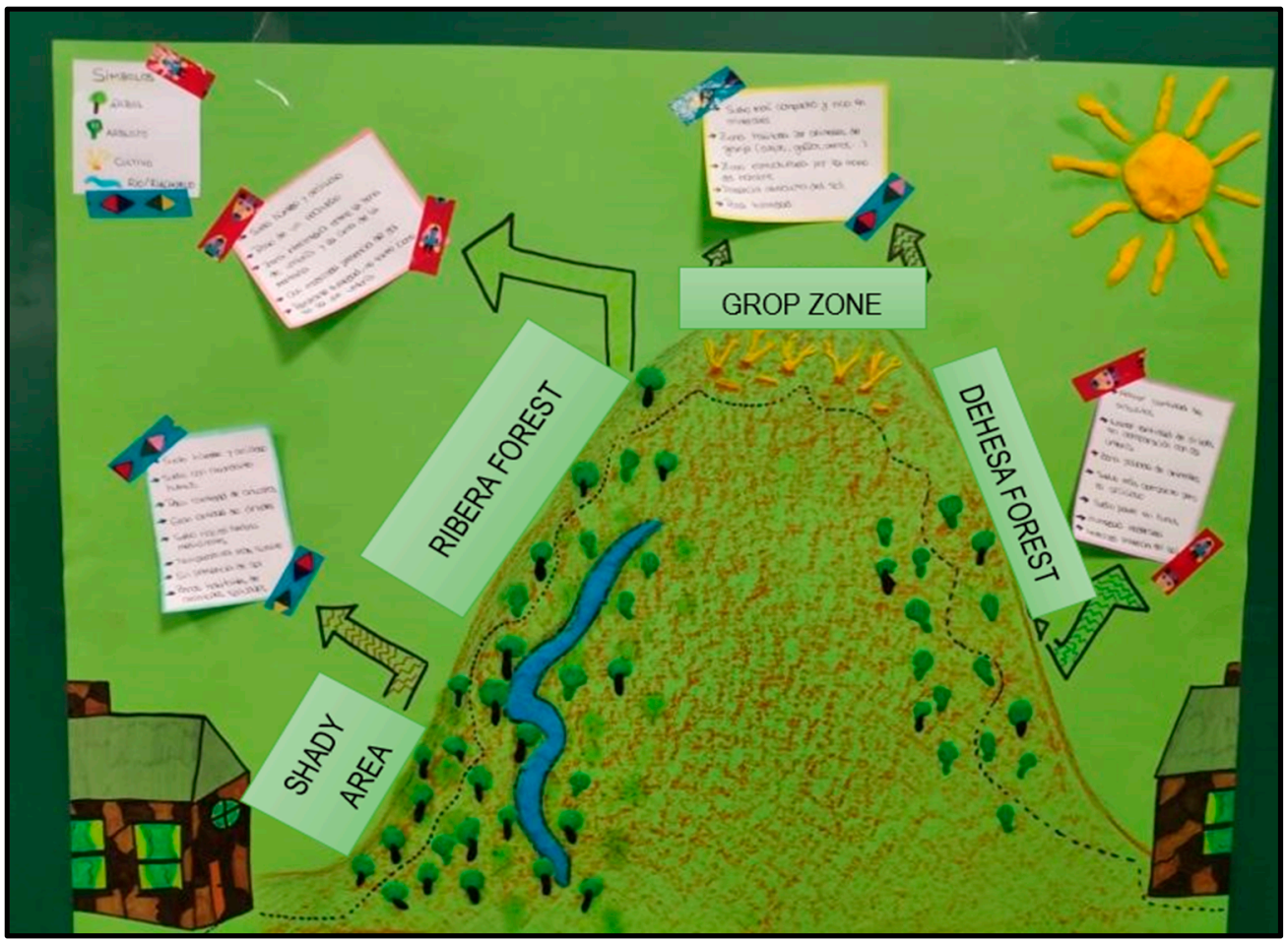

Figure 6. Educational itinerary (example D): category 1 (level III); category 2 (level II); category 3 (level III). [Source: adapted from student's work].

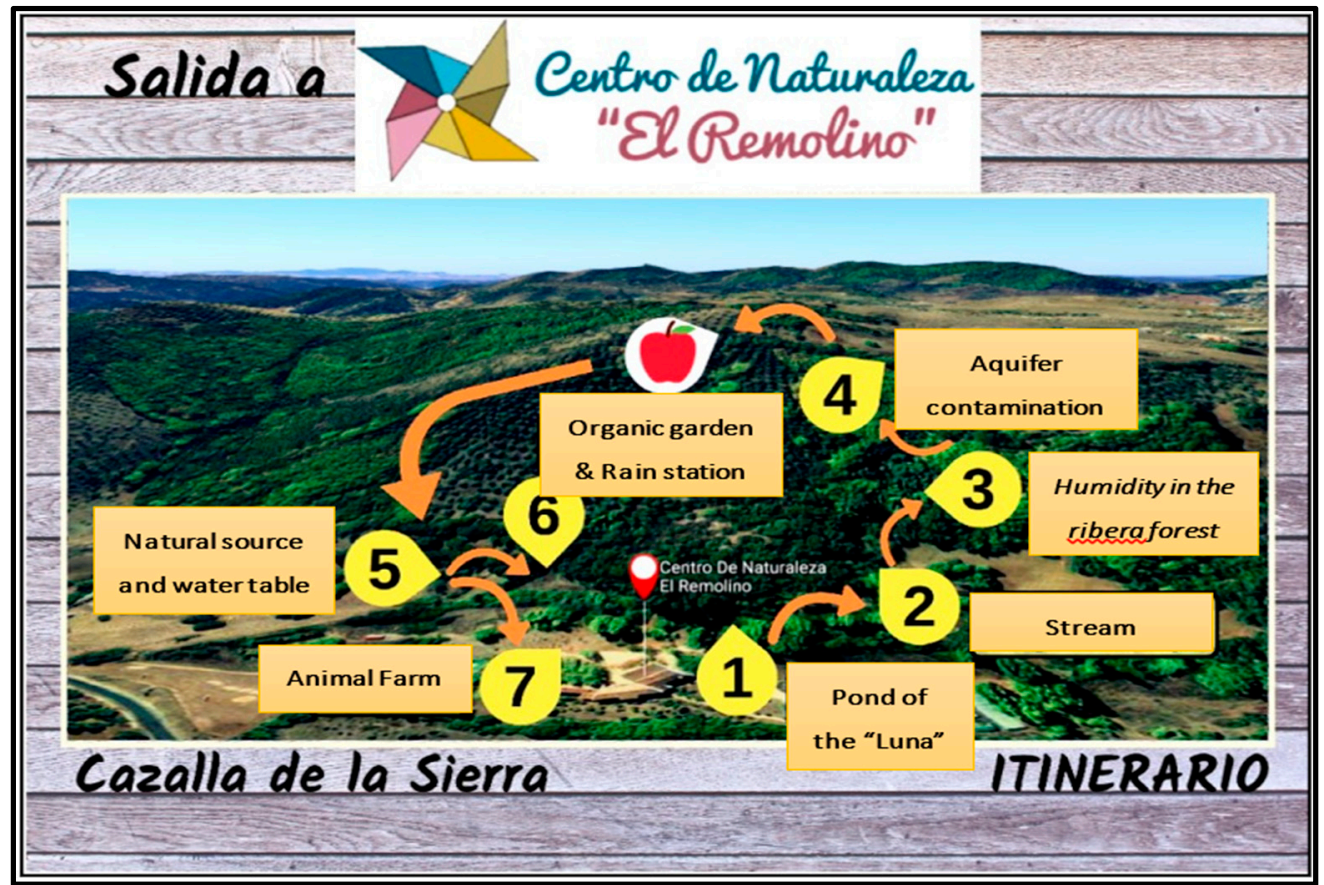

Figure 7. Educational itinerary (example E): category 1 (level III); category 2 (level III); category 3 (level III). [Source: adapted from student's work]

\subsection{Teaching Aspects}

This dimension is defined by the three remaining categories (4-6). In Figure 1, it can be seen that the majority of the groups $(16=57.14 \%)$ reach level II in category 4 (theme of the itinerary). This means that itineraries are designed without any clear educational purpose or educational link 
with which to carry out the outing. For category 5 (socio-natural elements), the students usually choose resources from the environment without establishing relationships between them (de-contextualized), i.e., there is a tendency for level I $(18=64.29 \%)$. Category 6 (designed activity) tends to be level II $(16=57.14 \%)$. Activities are presented with educational intent, but mainly of a traditional nature, not very interactive, and focused on the element as an object and not as a teaching resource. Two notable examples corresponding to the main levels reached are described in the following.

Example E. We see the design of a set of activities without any apparent common thread. The itinerary does have an explicit theme ("healthy habits"), and a possible educational objective. However, the objective does not correspond to the sequence of activities proposed, such as the soap workshop, or feeding farm animals. Thus, there are itineraries where the selected elements of the environment do not have a clear educational objective, and therefore contain little educational implication (Table 3). This same example also serves to illustrate level I of category 5 which is reached by most itineraries $(18=64.29 \%)$. The socio-natural elements of the environment that are selected to do the activities are imprecise (handkerchief game and sack race), de-contextualized with the place, and with little or no impact on the teaching-learning processes. In this sense, the Sierra de Cazalla offers multiple educational opportunities because of its wealth of elements and socio-natural resources. The design of activities such as soap workshops, handkerchief games, or sack races can be carried out in any other space.

Table 3. Example E: category 4 (level II); category 5 (level I); category 6 (level II).

\begin{tabular}{ll}
\hline \multicolumn{1}{c}{ Selected Theme } \\
Healthy habits. \\
\hline \multicolumn{1}{c}{ Designed activities } \\
1. $\quad$ Workshop for making soaps. \\
2. $\quad$ Feed farm animals. \\
3. $\quad$ Workshop for making bread. \\
4. $\quad$ Handkerchief game. \\
5. & Sack race. \\
\hline
\end{tabular}

Example G. We recognize another obvious case of level I in category 5 (Table 4). This proposal consists of six activities (six stops). The socio-natural elements chosen are flora (activities 1, 3, 4, and 5) and fauna (activity 2). The activities for the flora do not have any apparent relationship between them, much less allow that element to be connected with its environment or medium. Thus, for example, the navelwort is a plant that grows under determined temperature and humidity conditions, and consequently in specific places. This itinerary does not address aspects with educational relevance, only the descriptive and anecdotal characteristics of the plant so that it can be found. Activity 2, focused on observation on the part of the pupils, does not offer an explanation-for what reason and why-of the activity aimed at understanding some aspect of the ecosystem visited.

Finally, example $G$ also serves to illustrate the results of category 6 (level II: $16=57.14 \%$ ). In addition to selecting socio-natural elements that are apparently unrelated and will hardly at all promote any systemic vision of the environment, the proposed activities are traditional or not very interactive. The tasks focus on a socio-natural element as the object of study: in this case, the memorization of the name of a plant, its recognition, and its edible property, but with little relevance educationally. Therefore, useful educational opportunities are missed in which these elements could be used as teaching resources: with the plants, an approach could be made to the area's flora, its biodiversity, its vulnerability to contamination, its importance for the ecosystem or for human beings, the development of the local economy, etc. 
Table 4. Example G: category 4 (level II); category 5 (level I); category 6 (level II).

Selected Theme
Unspecified.
Designed activities
1. Each child looks for a tree or flower that catches their attention, picks a leaf from the tree or flower, and
then sticks it onto a card. Later there is an explanation about each of the plants chosen by the pupils.
2. At the pond, the children must observe the different animals living there, mainly frogs, tadpoles, and
3. The pupils look for a plant (goosegrass) guided by the teacher's explanations.
4. They will be given some edible plants to taste.
5. The pupils look for a plant (navelwort) guided by the teacher's explanations.
6. Brainstorming at the conclusion of the visit.

\section{Discussion}

EIs are a teaching resource of great value that allows the prospective teachers to test their scientific and cartographic knowledge and their teaching skills in the design of meaningful and coherent activities. With this type of experience, other spaces are valued as a potential teaching resource, thus promoting the design of outdoor activities. Likewise, although this experience was carried out with two different groups (area of Sciences Education and area of Social Sciences Education), no differences in the results were found between them. This could be because we work with both groups from the same interdisciplinary perspective (as science issues as social issues) and share subject during their Bachelor Degree. We designed a rubric to assess these productions. After the analysis of the different EIs, we tried to respond to the different research questions to finally detect what training needs the prospective teachers demanded. We shall establish the conclusions based on the two main dimensions of the rubric-from the perspectives of the formal and of the teaching aspects.

Regarding the formal aspects, most of the itineraries tended to be level I-II. The students had difficulty recognizing the minimum elements that make up the itineraries: they did not represent geographically or locate (more or less roughly) the selected socio-natural elements or landmarks that made up the stops. We also found some representations that could not be classified as itineraries either, since they do not establish any clear sense or direction of the path, and they present elements that are isolated or unrelated to the environment in which they are found. Consequently, we can point out two major training needs of future primary teachers to improve. The first in relation to the itinerary as an educational resource (what to understand by itinerary and the elements that make it up). And the second one related to the teaching of basic geographic and cartographic knowledge [46,60]. Related to this need, the work of Alcántara \& Medina [49] offers a proposal to carry out EIs in an interdisciplinary way, and with cartographic and scientific knowledge using Geographic Information Systems (GIS) and Google Earth. Therefore, it would be recommendable to develop further interdisciplinary and coordinated teaching experiences such as the one presented here.

Regarding the teaching aspects, from the EI theme, the socio-natural elements selected, and the type of activities proposed, many of these categories reached level I-II or II. In general, we can say that few EIs use the socio-natural elements of the area as an object and a resource. On the contrary, the vast majority presented activities that are de-contextualized between the proposed educational objective and the element used for that purpose. Either the designed activities remained merely anecdotal (without any educational objective) or were traditional and not very interactive.

\section{Conclusions}

These results highlight two major training necessities for future teachers. On the one hand, there is the difficulty in "uprooting" traditional teaching models focused on receiving information from the memorization or the incorporation of data $[2,61]$. On the other hand, there is the need to improve the 
students' scientific skills (observation, relationships between variables, inferences, etc.) and scientific knowledge about their neighbouring environment and its biodiversity for them to be able to construct a concept of environment from a systemic view of the processes involved [15,62].

Also noteworthy is the need to overcome certain difficulties and obstacles for the understanding and construction of geographic and spatial notions, essential to understand the environment as a system. With the title of this work, we have wanted to display that our results allow an approach for future teachers' conceptualization of the environment and biodiversity. Many of these students build their notion of a territory based on the concept of the environment as a setting in which the different types of elements and phenomena have no apparent connection with the geographic space they belong to. From the systemic and holistic view of the environment and biodiversity, the future teachers' partial and biased conception is a major hindrance against being able to offer an adequate educational treatment in Primary Education [12,14,63,64]. For this reason, the future teachers cannot design good outdoor activities, much less from Inquiry-Based science education approach (as a reference level), if they do not even know about their own immediate environment $[65,66]$. In this situation, they would not be able to use the environment as a teaching resource.

However, analysing the EIs in accordance with the set of categories that make up the rubric helps to objectively and systematically evaluate the students' designs. Although the analysis offered by the rubric is individual, category by category, its organization into two large dimensions allows us to get an overall view of the EIs.

As noted above, there are no precedents of other instruments or previous research to objectively value EIs from our perspective. This first proposal or rubric can be improved after other experiences, and then become a potential instrument to be integrated into the initial teacher training curriculum from a formative and evaluative point of view [67].

To conclude, this study has shown us the importance that this type of teaching experience is taking on in the international scene. Therefore, as educators we must encourage field trips in teacher training, as other studies defend [15], and be able to develop evaluation instruments that are consistent with this practice.

\section{Limitations of the Study}

The study would be more complete if it had been replicated in other contexts. For this reason, this work should be understood as an approximation to the phenomenon that has served to validate the analysis rubric described here and which will be used and improved in future outdoor experiences.

Author Contributions: Conceptualization, H.M.-M., M.d.C.M.-M. and M.P.D.N.; methods, H.M.-M.; formal analysis, H.M.-M.; investigation, H.M.-M. and M.d.C.M.-M.; data curation, H.M.-M. and D.A.-L.; writing-original draft preparation, H.M.-M.; writing—review and editing, H.M.-M.; M.d.C.M.-M., D.A.-L., and M.P.D.N. All authors have read and agreed to the published version of the manuscript.

Funding: This research is part of the project I+D EDU2017-82505-P, was funded by the Economic, Industry and Competitive Ministry (Spanish Government).

Conflicts of Interest: The authors declare no conflict of interest.

\section{References}

1. Pedrinaci, E.; García de la Torre, E.; Sequeiros, L. El trabajo de campo y el aprendizaje de la Geología. Alambique Didáct. Cienc. Exp. 1994, 2, 37-46.

2. Fernández-Ferrer, G.; González-García, F. Salidas de campo y desarrollo competencial. Enseñ. Cienc. Tierra 2017, 25, 295-301. Available online: https://www.raco.cat/index.php/ECT/article/view/330134/420944 (accessed on 20 June 2020).

3. Morón, H.; Hamed, S.; Morón, M.C. ¿Cómo usan los futuros maestros de ciencias el medio socio-natural en el diseño de Itinerarios didácticos?: Algunos resultados y obstáculos de aprendizaje. In Investigación, Innovación Docente y TIC. Nuevos Horizontes Educativos; Alonso, S., Romero, J.M., Rodríguez-Jiménez, C., Sola, J.M., Eds.; Dykinson: Madrid, Spain, 2019; pp. 1754-1768. 
4. Loynes, C.; Michie, D.; Smith, C. Justifying outdoor education in the formal and informal curriculum. In $A$ Guide for Outdoor Educators in Scotland; Higgins, P., Loynes, C., Crowther, N., Eds.; Adventure Education: Penrith, UK, 1997; pp. 15-21.

5. Lee, H.; Stern, M.J.; Powell, R.B. Do pre-visit preparation and post-visit activities improve student outcomes on field trips? Environ. Educ. Res. 2020, 26, 989-1007. [CrossRef]

6. Orion, N.; Hofstein, A. Factors that influence learning during a scientific field trip in a natural environment. J. Res. Sci. Teach. 1994, 31, 1097-1119. [CrossRef]

7. Coll, S.D.; Coll, R.; Treagust, D. Making the most of out-of-school visits: How does the teacher prepare? Part I: Development of the Learner Integrated Field Trip Inventory (LIFTI). Int. J. Innov. Sci. Math. Educ. 2018, 26, 1-19. Available online: https://pdfs.semanticscholar.org/bde7/456d7db684a5179102c9bfd0e5d6a82c8424.pdf? _ga=2.156767099.1952557652.1592839419-812402438.1592839419 (accessed on 18 June 2020).

8. Patrick, P.; Mathews, C.; Tunnicliffe, S.D. Using a field trip inventory to determine if listening to elementary school students' conversations, while on a zoo field trip, enhances preservice teachers' abilities to plan zoo field trips. Int. J. Sci. Educ. 2013, 35, 2645-2669. [CrossRef]

9. Barnes, C.J. Preparing preservice teachers to teach in a culturally responsive way. Negro Educ. Rev. 2006, 57, 85-100. Available online: http://citeseerx.ist.psu.edu/viewdoc/download?doi=10.1.1.458.3111\&rep=rep1\& type $=$ pdf (accessed on 17 June 2020).

10. Díaz, M. Distribución del arbolado y persistencia a largo plazo de las dehesas: Patrones y procesos. Rev. Ecosistemas 2014, 23, 5-12. [CrossRef]

11. Harlen, W. (Ed.) Principles and Big Ideas of Science Education; Association for Science Education: Hatfield, UK, 2010; Available online: https://www.ase.org.uk/bigideas (accessed on 2 February 2020).

12. Bermúdez, G.M.A.; De Longhi, A.L.; Gavidia, V. El tratamiento de los bienes y servicios que aporta la biodiversidad en manuales de la educación secundaria española: Un estudio epistemológico. Rev. Eureka Sobre Enseñanza Divulg. Cienc. 2016, 13, 527-543. Available online: http://hdl.handle.net/10498/18495 (accessed on 10 March 2020).

13. García Gómez, J.; Martínez, F.J. Cómo y qué enseñar de la biodiversidad en la alfabetización científica. Enseñ. Cienc. Rev. Investig. Exp. Didáct. 2020, 28, 175-184. Available online: https://www.raco.cat/index.php/ Ensenanza/article/view/199611/353385 (accessed on 28 January 2020).

14. Caurín, A.; Martínez, M.J. Análisis del concepto de biodiversidad en los libros de texto de segundo ciclo de primaria en la Comunidad Valenciana (España). Perf. Educ. 2013, 35, 97-114. [CrossRef]

15. Schneiderhan-Opel, J.; Bogner, F.X. Between Environmental Utilization and Protection: Adolescent Conceptions of Biodiversity. Sustainability 2019, 11, 4517. [CrossRef]

16. Rubio, J.M. Biogeografía. Paisajes Vegetales y Vida Animal; Síntesis: Madrid, Spain, 1988.

17. Costa, J.C.; Martín, A.; Fernández, R.; Estirado, M. Dehesas de Andalucía. Caracterización Ambiental; Consejería de Medio Ambiente (Junta de Andalucía): Sevilla, Spain, 2006; Available online: https://www.juntadeandalucia.es/medioambiente/portal_web/web/servicios/centro_de_documentacion_ y_biblioteca/fondo_editorial_digital/documentos_tecnicos/dehesas_andaluzas/dehesas_andaluzas.pdf (accessed on 27 February 2020).

18. Ojeda, J.F.; Silva, R. Dehesas de Sierra Morena y políticas agroambientales comunitarias. Estud. Geogr. 1997, 57, 203-226. [CrossRef]

19. Morón, H.; Morón, M.C. ¿Educación Patrimonial o Educación Ambiental? Perspectivas que convergen para la enseñanza de las ciencias. Rev. Eureka Sobre Enseñ. Divulg. Cienc. 2017, 14, 244-257. [CrossRef]

20. National Research Council. Assessing 21st Century Skills: Summary of a Workshop; The National Academies Press: Washington, DC, USA, 2011.

21. Rocard, M.; Csermely, P.; Jorde, D.; Lenzen, D.; Walwerg Henriksson, H.; Hemmo, V. Informe Rocard—Enseñanza de las Ciencias Ahora: Una Nueva Pedagogía para el Futuro de Europa; European Comission: Brussels, Belgium, 2007.

22. COSCE. Informe Enciende: Enseñanza de las Ciencias en la Didáctica Escolar para Edades Tempranas en España; Rubes Editorial: Madrid, Spain, 2011; Available online: https://www.cosce.org/pdf/Informe_ENCIENDE.pdf (accessed on 10 January 2020).

23. Organic Law 8/2013, 9 December, for the Improvement of Educational Quality; Ministerio de la Presidencia (Boletín Oficial del Estado, 295): Madrid, Spain, 2013; pp. 97858-97921; Available online: https://www.boe.es/boe/ dias/2013/12/10/pdfs/BOE-A-2013-12886.pdf (accessed on 16 January 2020). 
24. Order 17 March 2015, por la que se Desarrolla el Currículo Correspondiente a la Educación Primaria en Andalucía; Consejería de Educación de la Junta de Andalucía (Boletín Oficial de la Junta de Andalucía, 60): Sevilla, Spain, 2015; pp. 9-696; Available online: https://www.juntadeandalucia.es/boja/2015/60/1 (accessed on 30 January 2010).

25. Souto, X.M. El espacio cotidiano como objeto de aprendizaje en las primeras edades escolares (3-8 años). In Didáctica de la Geografía. Problemas Sociales y Conocimiento del Medio; Souto, X.M., Ed.; Del Serbal: Barcelona, Spain, 1998; pp. 221-241.

26. Vilarrasa, A. Salir del aula. Reapropiarse del contexto. Íber. Didáct. Cienc. Soc. Geogr. Hist. 2006, 9, $13-25$.

27. Romero-Ariza, M. El aprendizaje por indagación: ¿existen suficientes evidencias sobre sus beneficios en la enseñanza de las ciencias? Rev. Eureka Sobre Enseñ. Divulg. Cienc. 2017, 14, 286-299. [CrossRef]

28. Couso, D. De la moda de "aprender indagando" a la indagación para modelizar: Una reflexión crítica. In Investigación y Transferencia para una Educación en Ciencias: Un Reto Emocionante; Heras, M.A., Lorca, A., Vázquez, B., Wamba, A., Jiménez, R., Eds.; Servicio de Publicaciones Universidad de Huelva: Huelva, Spain, 2014; pp. 1-28.

29. Blanca, S.; Hidalgo, J.; Burgos, C. Escuela infantil y ciencia: La indagación científica para entender la realidad circundante. Enseñ. Cienc. Rev. Investig. Exp. Didáct. 2013, 979-983. Available online: https://www.raco.cat/index.php/Ensenanza/article/view/295136/383783 (accessed on 16 June 2020).

30. Lederman, N.G.; Lederman, J.S.; Antink, A. Nature of science and scientific inquiry as contexts for the learning of science and achievement of scientific literacy. Int. J. Educ. Math. Sci. Technol. 2013, 1, 138-147. Available online: https://files.eric.ed.gov/fulltext/ED543992.pdf (accessed on 19 June 2020).

31. Garritz, A. Naturaleza de la ciencia e indagación: Cuestiones fundamentales para la educación científica del ciudadano. Rev. Iberoam. Educ. 2006, 42, 127-152. Available online: https://rieoei.org/historico/documentos/ rie42a07.pdf (accessed on 16 June 2020).

32. Abd-el Khalik, F.; BouJaoude, S.; Duschl, R.; Lederman, N.G.; Mamlok Naaman, R.; Hofstein, A.; Niaz, M.; Treagust, D.; Tuan, L. Inquiry in science education: International perspectives. Sci. Educ. 2004, 88, 397-419. [CrossRef]

33. Zamalloa, T.; Sanz, J.; Maguregi, G.; Fernández, L.; Echevarría, I. Acercar la geodiversidad a través de las salidas de campo en la ESO. Una investigación con el profesorado de ciencias de Bizkaia. Enseñ. Cienc. Rev. Investig. Exp. Didáct. 2014, 32, 443-467. [CrossRef]

34. Morales, A.J.; Caurín, C.; Sendra, C.; Parra, M. Aprendiendo a plantear problemas en el medio. Análisis de una experiencia con estudiantes del Máster de Investigación en Didácticas. Didáct. Cienc. Exp. Soc. 2014, 28, 68-81. [CrossRef]

35. Tal, R.T.; Morag, O. Refective practice as a means for preparing to teach outdoors in ecological garden. J. Sci. Teach. Educ. 2009, 20, 245-262. [CrossRef]

36. Amórtegui, E.; Mayoral, O.; Gavidia, V. Aportaciones de las Prácticas de Campo en la formación del profesorado de Biología: Un problema de investigación y una revisión documental. Didáct. Cienc. Exp. Soc. 2017, 32, 153-170. [CrossRef]

37. Costillo, E.; Borrachero, A.B.; Villalobos, A.M.; Mellado, V.; Sánchez, J. Utilización de la modelización para trabajar salidas al medio natural en profesores en formación de educación secundaria. Bio-Grafía Escr. Sobre Biol. Enseñ. 2014, 7, 165-175. Available online: https://revistas.pedagogica.edu.co/index.php/bio-grafia/ article/view/3000 (accessed on 3 February 2020).

38. Preston, L. Making connections with nature: Bridging the theory-Practice gap in outdoor and environmental education. J. Outdoor Environ. Educ. 2004, 8, 12-19. [CrossRef]

39. Toro, F.J.; Garrido, J.; Hernández, R. "Vuelta a la naturaleza”: La enseñanza de la Geografía y el trabajo de campo según los principios de la escuela moderna. In La Reconfiguración del Medio Rural en la Sociedad de la Información. Nuevos Desafíos en la Educación Geográfica; Macía, X., Armas, F., Rodríguez, F., Eds.; Andavira: Santiago de Compostela, Spain, 2019; pp. 1351-1360.

40. Collado, S.; Corraliza, J.A. Conciencia Ecológica y Bienestar en la Infancia. Efectos de la Relación con la Naturaleza; CCS: Madrid, Spain, 2016.

41. Boyle, A.; Conchie, S.; Maguire, S.; Martin, A.; Milsom, C.; Nash, R.; Rawlinson, S.; Turner, A.; Wurthmann, S. Fieldwork is Good: The Student Perception and the Affective Domain. J. Geogr. High Educ. 2007, 31, $299-317$. [CrossRef] 
42. Mateo, M.R. Las salidas de campo en el medio rural. Análisis de las investigaciones presentadas a congresos del grupo de trabajo de didáctica de la geografía de la AGE y de la APG (1988-2016). In La Reconfiguración del Medio Rural en la Sociedad de la Información. Nuevos Desafíos en la Educación Geográfica; Macía, X., Armas, F., Rodríguez, F., Eds.; Andavira: Santiago de Compostela, Spain, 2019; pp. 1279-1292.

43. Sanmartí, N. Didáctica de las Ciencias en la Educación Secundaria Obligatoria; Síntesis: Madrid, Spain, 2002.

44. Aguilera, D. La salida de campo como recurso didáctico para enseñar ciencias. Una revisión sistemática. Rev. Eureka Sobre Enseñ. Divulg. Cienc. 2018, 15, 3103-3117. [CrossRef]

45. Jerez, O. La transferencia de conocimientos didácticos-geográficos en el medio rural. El senderismo didáctico como propuesta para un desarrollo rural sostenible. In La Reconfiguración del Medio Rural en la Sociedad de la Información. Nuevos Desafíos en la Educación Geográfica; Macía, X., Armas, F., Rodríguez, F., Eds.; Andavira: Santiago de Compostela, Spain, 2019; pp. 1321-1333.

46. Guerra, F.J. Guías Prácticas Voluntariado Ambiental. Diseño de Itinerarios en el Medio Natural; Consejería de Medio Ambiente (Junta de Andalucía): Seville, Spain, 2010.

47. Olave, D. El itinerario didáctico: Una propuesta metodológica para el análisis geo-histórico local. Geoenseñanza 2005, 10, 197-208. Available online: https://www.redalyc.org/pdf/360/36010206.pdf (accessed on 30 March 2020).

48. Liceras, Á. Los itinerarios didácticos en la enseñanza de la geografía. Reflexiones y propuestas acerca de su eficacia en educación. Rev. Unes. Univ. Esc. Soc. 2018, 5, 66-81. Available online: https: //www.revistaunes.com/index.php/revistaunes/article/view/64/52 (accessed on 14 January 2020).

49. Alcántara, J.; Medina, S.M. El uso de los itinerarios didácticos (SIG) en la educación ambiental. Enseñ. Cienc. Rev. Investig. Exp. Didáct. 2019, 37, 173-188. [CrossRef]

50. Caamaño, A. Los trabajos prácticos en ciencia. In Enseñar Ciencias; Jiménez, M.P., Ed.; Barcelona: Barcelona, Spain, 2003; pp. 95-118.

51. Mata-Olmo, R.; Sanz-Herráiz, C. Los paisajes de Andalucía. In Geografía de Andalucía; López Ontiveros, A., Ed.; Ariel: Barcelona, Spain, 2003; pp. 847-878.

52. Porlán, R.; Azcárate, P.; Martín, R.; Rivero, A. Conocimiento profesional deseable y profesores innovadores: Fundamentos y principios formativos. Investig. ESC 1996, 29, 23-38. Available online: https://revistascientificas.us.es/index.php/IE/article/view/8088/7147 (accessed on 3 February 2020).

53. Alonzo, A.C. Exploring the learning progression-formative assessment hypothesis. Appl. Meas. Educ. 2018, 31, 101-103. [CrossRef]

54. Gunckel, K.L.; Covitt, B.A.; Salinas, I.; Anderson, C.W. A learning progression for water in socio-ecological systems. J. Res. Sci. Teach. 2012, 49, 843-868. [CrossRef]

55. Creswell, J.W.; Poth, C.N. Qualitative Inquiry and Research Design: Choosing among Five Approaches; Sage Publications: London, UK, 2016.

56. Cruz-Guzmán, M.; Puig Gutiérrez, M.; García-Carmona, A. ¿Qué tipos de actividades diseñan e implementan en el aula futuros docentes de Educación Infantil cuando enseñan ciencia mediante rincones de trabajo? Enseñ. Cienc. 2020, 38, 27-45. [CrossRef]

57. Astolfi, J.P. El "Error", un Medio para Enseñar; Díada: Seville, Spain, 1999.

58. García, J.E. Una hipótesis de progresión sobre los modelos de desarrollo en Educación Ambiental. Investig. ESC 1999, 37, 15-27. Available online: https://revistascientificas.us.es/index.php/IE/article/view/7840/6939 (accessed on 5 March 2020).

59. García, J.E. Educación Ambiental, Constructivismo y Complejidad; Díada: Seville, Spain, 2004.

60. Morón, H.; Wamba, A.M. La percepción sobre los riesgos ambientales como indicador de los obstáculos y dificultades para la construcción de un concepto de medio ambiente responsable. Bio-Grafía Escr. Sobre Biol. Enseñ. 2010, 3, 114-137. [CrossRef]

61. García Gajardo, F.; Fonseca, G.; Concha, L. Aprendizaje y rendimiento académico en educación superior: Un estudio comparado. Rev. Electrón. Actual Investig. Educ. 2015, 15, 1-26. Available online: https: //www.redalyc.org/pdf/447/44741347019.pdf (accessed on 22 February 2020).

62. De-Juanas Oliva, A.; Martín Del Pozo, R.; González Ballesteros, M. Competencias docentes para desarrollar la competencia científica en educación primaria. Bordón 2016, 68, 103-120. [CrossRef]

63. Van Weelie, D. Making biodiversity meaningful through environmental education. Int. J. Sci. Educ. 2002, 24, 1143-1156. [CrossRef] 
64. Grace, M. Developing high quality decision-making discussions about biological conservation in a normal classroom setting. Int. J. Sci. Educ. 2009, 31, 551-570. [CrossRef]

65. López de Haro, L.; Segura-Serrano, J.A. Los itinerarios didácticos: Un recurso interdisciplinar y vertebrador del curriculum. Espiral. Cuad. Profr. 2013, 6, 15-31. [CrossRef]

66. Palacios Mena, N.; Ramiro Roca, E. El aprendizaje de las ciencias sociales desde el entorno: Las percepciones de futuros maestros en el Geoforo Iberoamericano de Educación. Rev. Bibliogr. Geogr. Cienc. Soc. 2017, 22, 1-22. Available online: https://revistes.ub.edu/index.php/b3w/article/view/26431/27846 (accessed on 2 April 2020).

67. Dal Ré Carneiro, C.; Wagner, P. Actividades de campo en la asignatura Ciencia del Sistema Tierra: La Geología como estructura básica. Enseñ. Cienc. Tierra 2011, 19, 48-56. Available online: https://www.raco.cat/index. php/ECT/article/view/244378/331350 (accessed on 10 April 2020).

C 2020 by the authors. Licensee MDPI, Basel, Switzerland. This article is an open access article distributed under the terms and conditions of the Creative Commons Attribution (CC BY) license (http://creativecommons.org/licenses/by/4.0/). 